\title{
Effect of Inspiratory Muscle Training on Clinical Outcomes of Patients Undergoing Cardiothoracic Surgeries
}

\author{
Nadia Eleter ${ }^{1}$, AfafBasal $^{2}$, Hend El-Azazy ${ }^{3}$, ElatafyElmetwaly ${ }^{4}$ \\ ${ }^{1 .}$ Assistant Lecturer of Critical Care Nursing-Faculty of Nursing-Tanta University \\ 2. Assist. Prof. of Medical Surgical Nursing- Faculty of Nursing- Tanta University \\ ${ }^{3 .}$ Assist. Prof. of Medical Surgical Nursing- Faculty of Nursing-Tanta University, Assist. Prof. of Medical \\ Surgical Nursing- Faculty of Nursing, KSAU,KSA. \\ 4. Assist. Prof. of Cardio-Thoracic Surgery- Faculty of Medicine-Tanta University
}

\begin{abstract}
Inspiratory muscle training is a therapeutic strategy that aimed at preventing post-operative pulmonary complications.

Aim: this study aimed to study the effect of inspiratory muscle training on clinical outcomes of patients underwent cardiothoracic surgeries.

Materials and Method: A quasi-experimental study was conducted in Cardiothoracic Surgery Department at Student Hospital affiliated to Tanta University. A sample of 40 adult patients of both sexes underwent cardiothoracic surgeries based on statistical power analysis were selected and divided into 2 equal groups:

Group 1 (Control Group): was received routine hospital care.

Group 2 (Study Group): was received pre and postoperative inspiratory muscle training which was implemented by the researcher. Three tools were used to collect data: Tool (I) Cardiothoracic Patient Assessment Tool. Tool II Cardiovascular and Respiratory System Assessment Tool,Tool III Clinical Outcome Assessment Tool. Results: The incidence of post-operative pulmonary complications was higher in the control group $(70 \%$ and $60 \%)$ while it was (30\% and $25 \%)$ of the study group during the $5^{\text {th }}$ and $7^{\text {th }}$ post-operative day respectively. Duration of stay in ICU was longer in thecontrol group4-17 days while it was 2-9 days in the study group. None of the study group compared to fifth (20\%) and fourth (25\%) of the control group needed reintubation and ICU readmission respectively. A high proportion of the study group (55\% and 70\%) had dyspnea relieved by practicing of inspiratory muscle training compared to none of the study group.

Conclusions and Recommendations: Inspiratory muscle training is an effective strategy in improving patient's outcomes after cardiothoracic surgery. It was recommended that all cardiothoracic surgical patients should receive pre and post-operative inspiratory muscle training as a daily routine care.
\end{abstract}

Keywords: Inspiratory muscle training, clinical outcomes

\section{Introduction}

Cardiothoracic surgery is associated with a significant risk of serious complications. So, cardiothoracic surgical patients require intensive care management postoperatively. Many of these complications are likely caused in some part by the exaggerated systemic inflammatory response to cardiopulmonary bypass (CPB).Postoperative pulmonary complications (PPCs) are the most frequently observed complications after cardiothoracic surgery, of which pneumonia and atelectasis are the most common.PPCs have significant clinical and economic impact associated with increasing morbidity, length of stay and associated cost ${ }^{(1-3)}$.

In Egypt Al-Qubati $\mathbf{2 0 1 3}^{(4)}$ stated that postoperative pulmonary complications occurred in $7.82 \%$ of patients with coronary artery revascularization, $2.23 \%$ in patients with valvular replacement and $5.05 \%$ in patients with congenital heart diseases. Acute Respiratory Distress Syndrome (ARDS) occurred in $3.35 \%$ of patients with a mortality rate of about $66.6 \%$, pneumonia in $2.79 \%$, atelectasis in $3.35 \%$, pleural effusion in $2.22 \%$ and pneumothorax in $0.55 \%$.

In Cardiothoracic Surgery Department at Tanta University Hospital (2014), about 200 patients underwent cardiothoracic surgeries ${ }^{(5)}$. A study conducted in Cardiothoracic Surgery Department, Faculty of Medicine Tanta university Hospital revealed that; the overall incidence of postoperative pulmonary complications was $64.4 \%$ and the mortality rate was $45.8 \%{ }^{(6)}$.

Postoperative pulmonary complications (PPCs) were defined as pulmonary abnormalities that produce identifiable disease or dysfunction that is clinically significant and adversely affects the clinical outcomes. PPCs may be due to preoperative, intraoperative or postoperative factors. Among the most common postoperative pulmonary complications are atelectasis, pneumonia, pneumothorax, hemothorax, pleural effusion, acute respiratory distress syndrome, pulmonary oedema, respiratory failure with prolonged mechanical ventilation and /or exacerbation of underlying chronic lungdisease ${ }^{(7-9)}$. 
Dysfunction of the respiratory muscles due to surgery may lead to decrease in vital capacity, tidal volume and total lung capacity. This causes atelectasis in basal lung segments and decreased functional residual capacity affecting gas exchange by increasing ventilation /perfusion (V/Q) mismatch. Patients with median sternotomy tend to take a shallow breath, thus retaining carbon dioxide and cause a wide range of postoperative pulmonary Complications ${ }^{(10-13)}$.

During the immediate postoperative period, the patient is admitted to the critical care unit. He is intubated and receives mechanical ventilation often up to 24 hours or more. After extubation the patient is provided supplemental oxygen via nasal cannula or face mask during the first 24 to 48 hours. Immediately after extubation the patient requires aggressive inspiratory muscle training ${ }^{(14,15)}$.

Critical care nurse plays a major role in preparing patients and families for operations. Preoperative instructions and psychological support are an integral component of nursing care. The nurse assesses the patient before surgery and plane for postoperative care. The critical care nurse has a vital role in detecting, preventing and managing the post-operative pulmonary complications throughout the perioperative period. The use of preoperative inspiratory muscle training strongly reduces the number of patients who developed postoperative pulmonary complications $(16,17)$.

Inspiratory Muscle Training (IMT) is a course of therapy consists of series of breathing and coughing exercises that aims at increasing ventilation, increasing total lung capacity, increasing inspiratory muscle strength, keeping air way clearance, preventing post-operative pulmonary complications, eliminating the useless uncoordinated pattern and decreases the work of breathing ${ }^{(18-22)}$.

Inspiratory muscle training (IMT) includes the following: incentive spirometry (IS), diaphragmatic breathing exercises, segmental breathing exercises (lateral costal expansion exercises, posterior costal expansion exercises, apical costal expansion exercises) and huff coughing exercises ${ }^{(23-25)}$.

Incentive spirometry (IS) involves using a hand held device to help the patient achieve maximal ventilation. IS provides the patients with a visual clue about inspiratory volume as to how well they are performing their deep breathing exercises and therefore may serve as a motivator or provides an incentive to their performance. Incentive spirometry is designed to replace the natural mechanism of sighing or yawning thus preventing and reversing the alveolar collapse that causes atelectasis and pneumonia ${ }^{(26,27)}$.

Diaphragmatic breathing is the breathing that promotes the use of the diaphragm. It is used to increase the volume of air exchanged during inspiration and expiration. Diaphragmatic breathing improves gas distribution at higher lung volumes, strengthen the diaphragm during breathing and decrease the energy cost of ventilation. Also, this technique includes pursed lip breathing technique during exhalation maneuver. It is usually practiced for at least 20 minutes two or three times daily ${ }^{(28,29)}$

Segmental breathing exercises are performed on a segment of the lung that needs increased ventilation or movement due to hypoventilation that occurs as a result of pain, muscle guarding after surgery, atelectasis and pneumonia. Segmental breathing exercises are used to prevent accumulation of fluid and to increase chest mobility by directing inspired air to predetermined areas. Segmental breathing exercises include lateral costal expansion, apical costal expansion and posterior costal expansion exercises ${ }^{(30,31)}$.

\section{Aim of the study}

The Aim of the study was to Study the effect of inspiratory muscle training on clinical outcomes of patients undergoing cardiothoracic surgeries.

\section{Materials and Method}

Study design: The present study was a quasi- experimental research design.

Setting: The study was conducted in Cardiothoracic Surgery Department at Student Hospital affiliated to Tanta University. It was consisted of two units, Open Heart Surgery and Chest Surgery Unit.

Sample: The sample of the study composed of 40 adult patients undergoing cardiothoracic surgeries in previously mentioned setting. They enrolled in this study according to the following inclusion criteria; Adult conscious patients with age ranging from 21-60 years old who were undergoing any elective open cardiothoracic surgery, both sex, Patients falling in first and second category of risk factors (good and fair outcome category) for postoperative pulmonary complications.

Patients who were undergoing emergent cardiothoracic surgery, falling in the $3^{\text {rd }}$ and $4^{\text {th }}$ category of risk factors for postoperative pulmonary complications and have history of a neuromuscular disorder were excluded from thesample.

\section{Tools of Data Collection}

Three tools were used by the researcher; 
Tool (I) Cardiothoracic Patient Assessment Tool:This tool was developed by the researcher after reviewing the related literature ${ }^{(32,33)}$ except part B which was developed by Parsonnet et al (1989) ${ }^{(34)}$ and it was consisted of 3 parts as follow:

Part A: Patient's Biosocio-Demographic Data:included;age, sex, marital status, educational level, occupation, body mass index, smoking history, diagnosis, previous hospitalization, type of cardiothoracic surgery, date of admission, date of operation, date of discharge, past medical history, past surgical history and post-operative medication.

\section{Part B: Preoperative Risk Scores for Postoperative Pulmonary Complications:}

This part was conducted through the use of Parsonnet Scale (1989) ${ }^{\mathbf{( 3 4 )}}$ and used in the preoperative period to assess postoperative morbidity and mortality. The scale was consisted of 13 items included; gender, morbid obesity, diabetes, hypertension, ejection fraction, age, reoperation, preoperative intraaorticballoon pump, dialysis dependent, pacemaker dependent, left ventricular aneurysm, emergency surgery and catastrophic state.

Part C: Laboratory Investigations and Diagnostic studies: which included: Arterial blood gases(ABG), White blood cell count per $\mathrm{mm}^{3}$, Sputum culture for isolation of different microorganisms and Chest $\mathrm{x}$-ray to diagnose postoperative pulmonary complications.

Tool (II) Cardiovascular and Respiratory System Assessment Tool: was developed by the researcher based on relevant literature ${ }^{(35,36)}$ to assess the effect of inspiratory muscle training on cardiovascular and respiratory system, it was consisted of 2 parts as follow:

Part A: Cardiovascular System Assessment: was consisted of pulse rate, blood pressure, postoperative pain which included site, radiation, quality, severity and duration, dyspnea which included type and relieving factors and cyanosis.

Part B: Respiratory System Assessment: was consisted of respiratory rate, depth, rhythm and symmetry of chest wall expansion, use of accessory muscles, presence of cough, sputum, hemoptysis and respiratory sounds.

Tool (III) Clinical Outcome Assessment Tool:This tool was used to assess the incidence of postoperative pulmonary complications and it was consisted of 2 parts as follow:

Part A:Melbourne Group Scale (MGS): This part was developed by Melbourne and modified by Bradley (2012) ${ }^{(37)}$ to assess the incidence of postoperative pulmonary complications and it was consisted of 8 categories (temperature more than $38^{\circ} \mathrm{C}$, physician diagnosis of pneumonia or chest infection, chest $\mathrm{x}$-ray report of atelectasis or consolidation, production of purulent (green /yellow) sputum differing from preoperative, positive signs of sputum microbiology, oxygen saturation $\left(\mathrm{Sao}_{2}\right)$ less than $90 \%$ on room air, white blood cell count greater than $11000 / \mathrm{mm}^{3}$,readmission to or prolonged stay over (36 hours) on the intensive care unit for respiratory problems) where clinically significant postoperative pulmonary complications were determined by the presence of 4 or more positive categories.

Part B: Clinical Outcome: This part was developed by the researcher after reviewing the related literature ${ }^{(38-40)}$ to assess the clinical outcomes of the inspiratory muscle training and consisted of the following items: duration of post-operative mechanical ventilation, duration of $\mathrm{O}_{2}$ therapy, need for re- intubation, need for chest tube reinsertion, length of postoperative ICU stay, need for ICU readmission and total period of hospitalization.

\section{A Pilot Study}

A pilot study was carried out on 4 patients undergoing cardiothoracic surgeries in order to test the clarity, feasibility and applicability of the different items of the determinant tools and accordingly;some modification was done and those patients were excluded from the study.

\section{Administrative Design and Ethical Considerations}

Official Permission to carry out the study was obtained from the responsible authoritiesSpecial training was demonstrated to the researcher by chest physiotherapist to gain perfection in inspiratory muscle training techniques and auscultation of respiratory sounds before starting the actual research study

Data were collected over a period of 7 months, started from December 2014 to June 2015.Verbal and written consent was obtained from the patients to participate in the study after explaining the purpose of the study and their right to refuse participation or withdrawn from the study at any time.Confidentiality and privacy were assured. 
Content Validity:All tools were tested for content validity by nine jury of experts in the field of medicalsurgical nursing, critical care nursing at the faculty of Nursing, cardiothoracic surgery, chest physiotherapists anesthesiologist at the faculty of medicine and accordingly some modifications were done.

The validity of the Parsonnet Scale was found to be $60 \%$.

The validity of Melbourne Group Scale was found to be $85 \%$ Reliability of the tool

Alpha Cronbach's test was used to test tool reliability and the estimated reliability of the entire test $=0.854$.

The reliability of the Parsonnet riskscale was found to be greater than 80.The reliability of Melbourne Group Scale was found to be about $90 \%$

Phases of the Actual Study: The present study was conducted on four phases.

1. Assessment phase:-

Immediately upon admission initial assessment was carried out by the researcher for all study subjects in both control and study groups to assess the patients who met the inclusive and exclusive criteria of the study. Assessment was done by using tool (I) part (A, B) to collect baseline data.

\section{Planning Phase:}

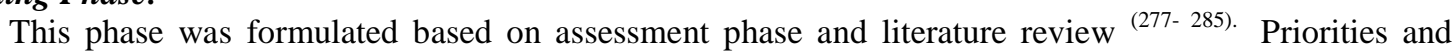
expected outcome criteria were put when planning patient care which included: reduction in the incidence of post-operative pulmonary complications, reduction of dyspnea, no need for re-intubation or chest tube reinsertion, reduced duration of post-operative mechanical ventilation, reduced duration of oxygentherapy and decreased the length of ICU stay and total days of hospitalization. In this phase, a colored booklet was developed by the researcher to be distributed to each patient in the study group to be considered as a reference value for the study group patients and their families.

\section{Implementation phase:}

In this phase, study group was encouraged to early mobilization and was received inspiratory muscle training (implemented by the researcher) as agreed by the treating physicians in the Open Heart and Chest Surgery Critical Care Units. Inspiratory Muscle Training was taught to all patients in the study group preoperatively in four sessions on every other day, each session has been taken a duration of 40 minutes and was given individually to each patient in the presence of one of the family members.

Inspiratory muscle training (incentive spirometry, diaphragmatic breathing, lateral costal expansion, posterior costal expansion, apical costal expansion and huff coughing exercises) was demonstrated by the researcher and then redemonstrated by the patient until the patient was performing the technique efficiently and correctly. The study group redemonstrated the inspiratory muscle training postoperatively immediately after extubation 30 minutes after taking the pain relieving medication.

Inspiratory muscle training was re-demonstrated postoperatively by patients in the study group in 5 sessions daily for one week, each session lasted for 40 minutes. In each session each type of exercises was redemonstrated 5 times and the patient is instructed to gradually increase the duration and frequency of exercises. Additionally, other positions such as sitting or standing may be used as the patient progress during treatment.

\section{Group (I): Control group}

Control group was exposed to routine hospital care as prescribed by cardiothoracic surgery team. The hospital routine of care was consisted of allowing the patient to move but not immediately when the patient became stable and pharmacological treatment of post-operative pulmonary complications only when they developed.

\section{Evaluation phase:}

Evaluation was done for both study and control groups using tool I part C (laboratory investigations and diagnostic studies) to evaluate the development of post-operative pulmonary complication, tool II (cardiovascular and respiratory system assessment tool) to evaluate the effect of inspiratory muscle training on cardiovascular and respiratory system post operatively and Tool III to evaluate the clinical outcomes of inspiratory muscle training after cardiothoracic surgeries five times in the $1^{\text {st }}$ day post-operatively and then three times daily for one week.

\section{Statistical analysis}

The collected data were organized, tabulated and statistically analyzed using SPSS software (Statistical Package for the Social Sciences, version 16. For quantitative data, the range, mean and standard deviation were calculated. For qualitative data, comparison between two groups and more was done using Chi-square test $\left(\chi^{2}\right)$.Significance was adopted at $\mathrm{p}<0.05$ for interpretation of results of tests of significance ${ }^{(41)}$. 


\section{Results}

The results of the present study revealed thatthe mean age of the control group was $39.00 \pm 9.14$, while it was $42.40 \pm 10.66$ in the study group. As for patient's sex, more than half $(55 \%)$ of the control group were males, where in the study group, half of them were males .In relation to marital status, an equal proportion $60 \%$ of the control and the study group were married. With regard to educational level, it was observed that less than half $40 \%$ of the control and near to half $45 \%$ of the study group had secondary school education level. Regarding occupation, half (50\%) of the control group and $40 \%$ of the study group were manual workers and $15 \%$ and $40 \%$ of the control and study group respectively were house wives.

Table 1:It was noticed that one fifth (20\%) of both the study and the control group had a diagnosis of coronary artery disease and lung cancer. About one third (30\%) of the control group and (35\%) of the study group had valve diseases.No statistical significant difference was observed between the studied groups regarding diagnosis where $\mathrm{p}=0.950$. Regarding the type of cardiothoracic surgery, it was found that one fifth (20\%) of control and study group had CABG and pneumectomy surgery. About one third (30\%) of control group and $(35 \%)$ of study group had valvularsurgery. It was observed that minority of the control and the study group (5\%) had resection of mediastinal mass and chest wall cancer. No statistical significant difference was observed between the studied groups regarding the type of cardiothoracic surgery where $\mathrm{p}=0.950$.

Figure 1: It was noticed that the mean values of pre-operative risk scale for post-operative pulmonary complications (Parsonnet risk scale) was $7.20 \pm 1.06$ and $8.75 \pm 0.44$ for control and the study group respectively andthe difference between the two groups was statically significant where $p=0.0001$ denoting that the study group subjects were at higher risk than those in the control group.

Table 2: Regarding PH during the $3^{\text {rd }}$ post-operative day, the mean \pm SD was reported as $7.40 \pm 0.05$ for the control group and $7.37 \pm 0.04$ for the study group. Regarding the partial pressure of arterial oxygen $\left(\mathrm{PaO}_{2}\right)$ during the $5^{\text {th }}$ and $7^{\text {th }}$ postoperative days, it was found that the mean \pm SD was $82.15 \pm 8.83$ and $83.50 \pm 10.97$ of the control group and $87.30 \pm 4.00$ and $90.85 \pm 3.22$ of the study group respectively. Statistical significant differences were found regarding $\mathrm{PH}$ during the $3^{\text {rd }}$ post-operative day and $\mathrm{PaO}_{2}$ during the $5^{\text {th }}$ and $7^{\text {th }}$ day postoperatively where $\mathrm{p}=0.031,0.023$ and 0.007 respectively.

Table 3: Regarding mean \pm SD of respiratory rate, it was noticed to be $(26.45 \pm 2.66$ and $25.60 \pm 3.07)$ of the control group, while it was $(23.25 \pm 2.65$ and $21.80 \pm 3.91)$ of the study group on the $5^{\text {th }}$ and $7^{\text {th }}$ post operative day respectively and statistical significant difference was found in relation to respiratory rate where $p=0.001$ and 0.002 during the $5^{\text {th }}$ and $7^{\text {th }}$ day post-operatively respectively.

Table 4: This table showed that $40 \%$ and $60 \%$ of the control group had dyspnea at rest compared to fifth (20\%) and tenth (10\%) of the study group during the $1^{\text {st }}$ and $3^{\text {rd }}$ post-operative day respectively. Less than two thirds $(60 \%)$ and less than half $45 \%$ of the control group compared to only tenth $(10 \%)$ and none of the study group had dyspnea on exertion during the $5^{\text {th }}$ and $7^{\mathrm{th}}$ post-operative day respectively. Statistical significant difference was found between the two groups related to dyspnea at rest and on exertion where $\mathrm{p}=0.0001$ and 0.003 respectively. Moreover, three quarters $(75 \%)$ and all $(100 \%)$ of the control group had dyspnea relieved by $\mathrm{O}_{2}$ therapy compared to an equal proportion (25\%) of the study group during the $1^{\text {st }}$ and $3^{\text {rd }}$ post-operative day respectively. In addition, about third (35\%) and more than half (55\%) of the study group had dyspnea relieved by practice of inspiratory muscle training compared to none of the control group during the $1^{\text {st }}$ and $3^{\text {rd }}$ postoperative day respectively. The differences between the two groups regarding relieving factors of dyspnea were statistically significant where $\mathrm{p}=0.0001$ and 0.010 respectively

Table 5: Regarding occurrence of post-operative pulmonary complications, a high proportion of the control group $(60 \% .65 \%, 70 \%$ and $60 \%)$ developed significant postoperative pulmonary complications compared to less proportion $(40 \%, 35 \%, 30 \%$ and $25 \%)$ of the study group during the $1^{\text {st }}, 3^{\text {rd }}, 5^{\text {th }}$ and $7^{\text {th }}$ post-operative day respectively. A statistical significant difference was found between the two groups regarding occurrence of postoperative pulmonary complications during the $5^{\text {th }}$ and $7^{\text {th }}$ post-operative days where $\mathrm{p}=0.011$ and 0.025 respectively.

Table 6:This table emphasized that themean \pm SD of control group for post-operative duration of mechanical ventilation was (5.25 \pm 4.49$)$ which was higher than that of the study group (2.60 \pm 2.37$)$. Regarding mean $\pm \mathrm{SD}$ of post-operative duration of $\mathrm{O}_{2}$ therapyof the control group was (5.15 \pm 2.16 ), which was longer than that of the study group (2.36 \pm 1.99$)$. Statistical significant differences were found between the two groups regarding mean 
values of post-operative duration of mechanical ventilation and duration of $\mathrm{O} 2$ therapy where $\mathrm{p}=0.025$ and 0.0001 respectively.

Figure 2: In relation to the need for post-operative re-intubation, this figure emphasized that none of the study group compared to one fifth of the control group needed re-intubation. The difference between the two groups related to need for re-intubation was statistically significant where $\mathrm{p}=0.035$. About one third $(30 \%)$ of the control group compared to tenth $(10 \%)$ of the study group needed chest tube re-insertion. The difference between the two groups regarding chest tube re-insertion was not statically significant where $\mathrm{p}=0.114$.

Table 7: Regarding mean values of duration of post-operative ICU admission, the mean \pm SD was $8.70 \pm 3.96$ of control group and $4.55 \pm 2.26$ of study group. A very high statistical significant difference was noted between the two groups regarding mean values of duration of post-operative ICU admission where $\mathrm{p}=0.0001$. In relation to mean values of total period of hospitalization, the mean \pm SD was $20.40 \pm 8.83$ of the control group while it was $15.20 \pm 8.11$ of the study group. Although there was no statistical significant difference between the control and the study groups regarding the mean values of total period of hospitalization where $\mathrm{p}=0.060$.

Figure 3: This figure emphasized that none of the study group compared to one fourth $25 \%$ of the control group needed postoperative I.C.U readmission. The difference between the two groups regarding the need for postoperative ICU re-admission was statistically significant where $\mathrm{p}=0.017$.

\begin{tabular}{|c|c|c|c|c|c|c|c|c|}
\hline \multirow[t]{3}{*}{ Variables } & \multicolumn{6}{|c|}{ The studied adult patients undergoing cardiothoracic } & \multirow[t]{3}{*}{$\chi^{2}$} & \multirow[t]{3}{*}{$\overline{\mathbf{P}}$} \\
\hline & \multicolumn{2}{|c|}{ Control group $(n=20)$} & \multicolumn{2}{|c|}{ Study group $(\mathrm{n}=\mathbf{2 0})$} & \multicolumn{2}{|c|}{ Total $(n=40$} & & \\
\hline & $\mathbf{N}$ & $\%$ & $\mathbf{n}$ & $\%$ & $\mathbf{N}$ & $\%$ & & \\
\hline Diagnosis: & & & & & & & & \\
\hline valvular diseases & 6 & 30.0 & 7 & 35.0 & 13 & 32.5 & 1.140 & 0.950 \\
\hline Coronary artery diseases & 4 & 20.0 & 4 & 20.0 & 8 & 20.0 & & \\
\hline Chronic empyema & 2 & 10.0 & 1 & 5.0 & 3 & 7.5 & & \\
\hline Lung cancer & 4 & 20.0 & 4 & 20.0 & 8 & 20.0 & & \\
\hline Chest wall cancer & 1 & 5.0 & 1 & 5.0 & 1 & 2.5 & & \\
\hline Mediastinal mass & 1 & 5.0 & 1 & 5.0 & 3 & 7.5 & & \\
\hline Congential heart diseases & 2 & 10.0 & 2 & 10.0 & 4 & 10.0 & & \\
\hline Type of cardiothoracic surgery: & & & & & & & & \\
\hline Valve surgery & 6 & 30.0 & 7 & 35.0 & 13 & 32.5 & 1.140 & 0.950 \\
\hline Coronary artery bypass graft & 4 & 20.0 & 4 & 20.0 & 8 & 20.0 & & \\
\hline Decortication of the lung & 2 & 10.0 & 1 & 5.0 & 3 & 7.5 & & \\
\hline Pneumectomy & 4 & 20.0 & 4 & 20.0 & 8 & 20.0 & & \\
\hline Chest wall cancer resection & 1 & 5.0 & 1 & 5.0 & 2 & 5.0 & & \\
\hline Mediastinal mass resection & 1 & 5.0 & 1 & 5.0 & 2 & 5.0 & & \\
\hline Repair of congenital heart diseases & 2 & 10.0 & 2 & 10.0 & 4 & 10.0 & & \\
\hline
\end{tabular}

Table 1:Clinical data of the studied adult patients undergoing cardiothoracic surgeries

Figure 1: Mean values of pre-operative risk scale for post-operative pulmonary complications (Parsonnet risk scale) of the studied adult patients undergoing cardiothoracic surgeries.

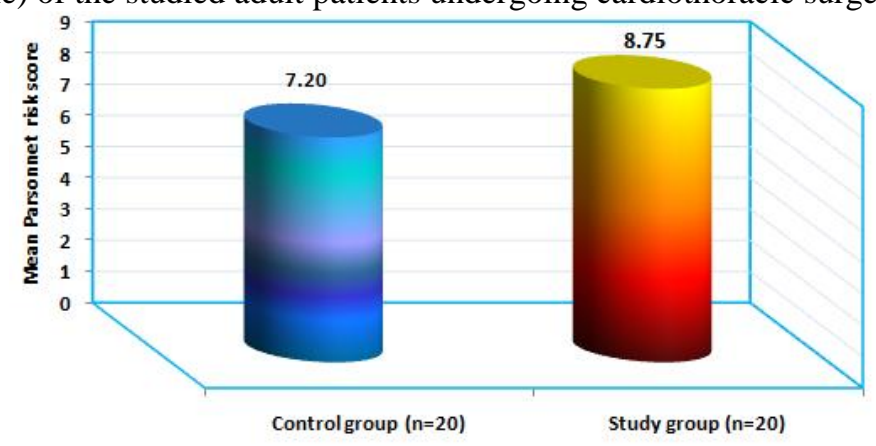

Mean value of pre-operative risk scores for post-operative pulmonary complications $(n=40)$ 
Effect of Inspiratory Muscle Training on Clinical Outcomes of Patients Undergoing Cardiothoracic...

Table 2: Mean values of arterial blood gases (ABGs) of the studied patientsundergoing cardiothoracic surgeries

\begin{tabular}{|c|c|c|c|c|}
\hline \multirow{3}{*}{$\begin{array}{c}\text { Laboratory } \\
\text { investigation of } A B G s \\
\text { of the studied patientsat } \\
\text { post-operative days }\end{array}$} & \multicolumn{2}{|c|}{$\begin{array}{c}\text { The studied patients undergoing cardiothoracic } \\
\text { surgeries }\end{array}$} & \multirow[t]{3}{*}{$\begin{array}{c}t- \\
\text { test }\end{array}$} & \multirow[t]{3}{*}{$\mathbf{P}$} \\
\hline & $\begin{array}{c}\text { Control group } \\
(\mathrm{n}=20)\end{array}$ & $\begin{array}{c}\text { Study group } \\
(\mathrm{n}=\mathbf{2 0})\end{array}$ & & \\
\hline & Mean \pm SD & Mean $=$ SD & & \\
\hline $\begin{array}{l}\text { PH at post-operative days: } \\
I^{\approx} \text { day }\end{array}$ & $\begin{array}{l}7.30-7.50 \\
7.39 \pm 0.05\end{array}$ & $\begin{array}{l}7.30-7.47 \\
7.37 \pm 0.04\end{array}$ & 1.566 & 0.126 \\
\hline $3^{n \infty} \mathrm{day}$ & $\begin{array}{l}7.33-7.51 \\
7.40 \pm 0.05\end{array}$ & $\begin{array}{l}730-7.46 \\
7.37 \pm 0.04\end{array}$ & $224 ?$ & $0.031^{*}$ \\
\hline $5^{\mathrm{en}} \mathrm{day}$ & $\begin{array}{l}730-7.51 \\
739 \pm 0.06\end{array}$ & $\begin{array}{l}733-7.46 \\
739 \pm 0.04\end{array}$ & 0.062 & 0951 \\
\hline $7^{0 \mathrm{n}} \mathrm{day}$ & $7.25-7.51$ & $\begin{array}{l}735-751 \\
738 \pm 0.03\end{array}$ & 0962 & 0342 \\
\hline $\begin{array}{l}\text { F value } \\
P\end{array}$ & $\begin{array}{l}0.242 \\
0.867\end{array}$ & $\begin{array}{l}\text { O.927 } \\
0.432\end{array}$ & & \\
\hline $\begin{array}{l}\mathrm{PaO}_{2} \text { at post-operative days: } \\
1=\text { day }\end{array}$ & $\begin{array}{c}77-91 \\
84.45 \pm 4.90\end{array}$ & $\begin{array}{c}75-95 \\
83.50 \pm 5.21\end{array}$ & 0.594 & 0.556 \\
\hline $3^{n s} \mathrm{day}$ & $\begin{array}{c}69-90 \\
83.15 \pm 5.30\end{array}$ & $\begin{array}{c}76-90 \\
83.15 \pm 4.16\end{array}$ & 0.000 & 1.000 \\
\hline $5^{m \mathrm{~d}} \mathrm{day}$ & $\begin{array}{c}53-91 \\
82.15 \pm 8.83\end{array}$ & $\begin{array}{c}79-93 \\
87.30 \pm 4.00\end{array}$ & 2376 & $0.023^{*}$ \\
\hline $7^{0 \mathrm{n}} \mathrm{day}$ & $\begin{array}{c}54-95 \\
83.50 \pm 10.97\end{array}$ & $\begin{array}{c}82-95 \\
90.85 \pm 3.22\end{array}$ & 2.876 & $0.007^{\circ}$ \\
\hline \multirow{2}{*}{$\begin{array}{l}\text { F value } \\
\text { P } \\
\text { Scheffe test } \\
P\end{array}$} & $\begin{array}{l}.288 \\
0.834\end{array}$ & $\begin{array}{c}14.859 \\
0.0001^{*}\end{array}$ & & \\
\hline & & 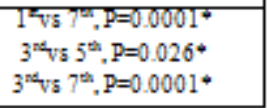 & & \\
\hline $\begin{array}{l}\text { Paco } 2 \text { at post-operatave days: } \\
I^{2} \text { day }\end{array}$ & $\begin{array}{c}34-49 \\
39.35 \pm 4.80\end{array}$ & $\begin{array}{c}29-50 \\
39.85 \pm 5.31\end{array}$ & 0.312 & 0.757 \\
\hline $3^{n \times} \mathrm{day}$ & $\begin{array}{c}30-50 \\
38.00 \pm 5.20\end{array}$ & $\begin{array}{c}33-50 \\
40.05 \pm 5.44\end{array}$ & 1218 & 0231 \\
\hline $5^{\mathrm{en}} \mathrm{day}$ & $\begin{array}{c}32-55 \\
40.10 \pm 5.94\end{array}$ & $\begin{array}{c}32-46 \\
37.10 \pm 3.29\end{array}$ & 1976 & 0.055 \\
\hline $7^{\mathrm{man}} \mathrm{day}$ & $\begin{array}{c}28-67 \\
40.25 \pm 8.64\end{array}$ & $\begin{array}{c}34-47 \\
37.25 \pm 2.93\end{array}$ & 1.470 & 0.150 \\
\hline $\begin{array}{l}F \text { value } \\
P\end{array}$ & $\begin{array}{l}0.528 \\
0.664\end{array}$ & $\begin{array}{l}2.001 \\
0.054\end{array}$ & & \\
\hline \multicolumn{4}{|l|}{$\mathrm{SaO}_{2}$ at post-operative days: } & 0.284 \\
\hline $3^{\text {st day }}$ & $\begin{array}{c}95.80 \pm 2.52 \\
91-100 \\
95.95 \pm 2.46\end{array}$ & $\begin{array}{c}96.60 \pm 2.11 \\
93-99 \\
96.35 \pm 1.50\end{array}$ & 0.621 & 0.538 \\
\hline $5^{\text {th }}$ day & $\begin{array}{c}80-99 \\
94.95 \pm 4.99\end{array}$ & $\begin{array}{c}93-100 \\
97.65 \pm 1.81\end{array}$ & 2.274 & $0.029^{*}$ \\
\hline $7^{\text {th day }}$ & $\begin{array}{c}82-99 \\
95.00 \pm 4.82\end{array}$ & $\begin{array}{c}95-99 \\
98.30 \pm 1.26\end{array}$ & 2.960 & $0.005^{*}$ \\
\hline \multirow{2}{*}{$\begin{array}{l}\text { F value } \\
\text { P } \\
\text { Scheffe test } \\
\text { P }\end{array}$} & $\begin{array}{l}0.362 \\
0.781\end{array}$ & $\begin{array}{c}5.738 \\
0.001^{*}\end{array}$ & & \\
\hline & & 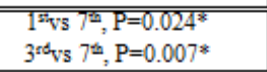 & & \\
\hline
\end{tabular}

*Significant $(\mathbf{P}<\mathbf{0 . 0 5})$ 
Effect of Inspiratory Muscle Training on Clinical Outcomes of Patients Undergoing Cardiothoracic...

Table 3: Mean values of respiratory rate (RR) of the studied adult patients undergoing cardiothoracic surgeries.

\begin{tabular}{|c|c|c|c|c|}
\hline \multirow[t]{3}{*}{$\begin{array}{c}\text { Respiratory rate (RR) } \\
\text { at post-operative days } \\
\text { of follow up }\end{array}$} & \multicolumn{2}{|c|}{$\begin{array}{c}\text { The studied adult patients } \\
\text { undergoing cardiothoracic } \\
\text { surgeries } \\
(\mathrm{n}=40)\end{array}$} & \multirow[t]{3}{*}{ t-test } & \multirow[t]{3}{*}{$\mathbf{P}$} \\
\hline & $\begin{array}{c}\text { Control group } \\
(\mathrm{n}=\mathbf{2 0 )}\end{array}$ & $\begin{array}{c}\text { Study group } \\
(\mathrm{n}=\mathbf{2 0})\end{array}$ & & \\
\hline & $\begin{array}{c}\text { Range } \\
\text { Mean } \pm \text { SD }\end{array}$ & $\begin{array}{c}\text { Range } \\
\text { Mean } \pm \text { SD }\end{array}$ & & \\
\hline \multirow[t]{2}{*}{$\begin{array}{l}\text { RR }(\mathrm{c} / \mathrm{m}) \text { at post- } \\
\text { operative days: } \\
1^{\text {st }} \text { day }\end{array}$} & $\begin{array}{c}20-30 \\
26.50 \pm 2.54\end{array}$ & $\begin{array}{c}20-30 \\
26.50 \pm 2.46\end{array}$ & 0.000 & 1.000 \\
\hline & $\begin{array}{c}22-30 \\
25.55 \pm 2.30\end{array}$ & $\begin{array}{c}20-29 \\
24.90 \pm 2.53\end{array}$ & 0.849 & 0.401 \\
\hline $5^{\text {th }}$ day & $\begin{array}{c}20-33 \\
26.45 \pm 2.66\end{array}$ & $\begin{array}{c}18-28 \\
23.25 \pm 2.65\end{array}$ & 3.805 & $0.001^{*}$ \\
\hline $7^{\text {th }}$ day & $\begin{array}{c}22-35 \\
25.60 \pm 3.07\end{array}$ & $\begin{array}{c}16-29 \\
21.80 \pm 3.91\end{array}$ & 3.417 & $0.002 *$ \\
\hline \multirow{2}{*}{$\begin{array}{l}\text { F value } \\
P \\
\text { Scheffe test } \\
P\end{array}$} & $\begin{array}{l}0.766 \\
0.517\end{array}$ & $\begin{array}{c}9.503 \\
0.0001^{*}\end{array}$ & & \\
\hline & & $\begin{array}{c}1^{\text {st }} \mathrm{vs} 5^{\text {th }} \& 7^{\text {th }} \\
\mathrm{P}=0.010^{*} \& \\
0.0001^{*} \\
3^{\text {rd }} \mathrm{vs} 7^{\text {th }} \\
\mathrm{P}=0.016^{*}\end{array}$ & & \\
\hline
\end{tabular}

*Significant $(\mathbf{P}<0.05)$

Table 4: Dyspnea and its relieving factors among the studied adult patients undergoing cardiothoracic surgeries.

\begin{tabular}{|c|c|c|c|c|c|c|c|c|c|c|c|c|c|c|c|c|c|c|c|c|c|c|}
\hline \multirow{4}{*}{$\begin{array}{l}\text { Dyspnea and its } \\
\text { relieving factors at } \\
\text { post-operative days } \\
\text { of follow up }\end{array}$} & \multicolumn{20}{|c|}{$\begin{array}{l}\text { The studied adult patients undergoing cardiothoracic surgeries at postoperative days of follow up } \\
\qquad(\mathrm{n}=40)\end{array}$} & \multirow{4}{*}{$\chi^{2}$} & \multirow{4}{*}{$P$} \\
\hline & \multicolumn{8}{|c|}{$\begin{array}{c}\text { Control group } \\
(\mathrm{n}=20)\end{array}$} & \multirow{3}{*}{$\chi^{2}$} & \multirow{3}{*}{$P$} & \multicolumn{8}{|c|}{$\begin{array}{c}\text { Study group } \\
(\mathrm{n}=\mathbf{2 0}\end{array}$} & \multirow{3}{*}{$\chi^{2}$} & \multirow{3}{*}{$P$} & & \\
\hline & \multicolumn{2}{|c|}{$1^{\text {st }}$} & \multicolumn{2}{|c|}{$3^{\text {rd }}$} & \multicolumn{2}{|c|}{$5^{\text {th }}$} & \multicolumn{2}{|c|}{$7^{\text {th }}$} & & & \multicolumn{2}{|c|}{$1^{\text {tt }}$} & \multicolumn{2}{|c|}{$3^{\text {rd }}$} & \multicolumn{2}{|c|}{$5^{\text {th }}$} & \multicolumn{2}{|c|}{$7^{\text {th }}$} & & & & \\
\hline & \begin{tabular}{l|l}
$\mathbf{n}$ & \\
\end{tabular} & $\%$ & $\mathbf{n}$ & $\%$ & $\mathbf{n}$ & $\%$ & $\mathbf{n}$ & $\%$ & & & $\mathbf{n}$ & $\%$ & $\mathbf{n}$ & $\%$ & $\mathbf{n}$ & $\%$ & $\mathbf{n}$ & $\%$ & & & & \\
\hline n\#·Dyspnea: & & & & & & & & & & & & & & & & & & & & & & \\
\hline At rest & 8 & 40.0 & 12 & 60.0 & 7 & 35.0 & 5 & 25.0 & 38.17 & $0.0001^{*}$ & 4 & 20.0 & 2 & 10.0 & 0 & 0 & 0 & 0 & 15.20 & $0.002^{*}$ & 14.20 & $0.0001 *$ \\
\hline On exertion & 0 & 0 & 4 & 20.0 & 12 & 60.0 & 9 & 45.0 & 23.74 & $0.0001^{*}$ & 0 & 0 & 7 & 35.0 & 2 & 10.0 & 0 & 0 & 19.60 & $0.0001^{i}$ & 8.533 & $0.003^{*}$ \\
\hline Orthopnea & 2 & 10.0 & 3 & 15.0 & 0 & 0 & 1 & 5.0 & 2.105 & 0.551 & 1 & 5.0 & 1 & 5.0 & 0 & 0 & 0 & 0 & 3.403 & 0.356 & 1.858 & 0.173 \\
\hline \begin{tabular}{c||c}
$\begin{array}{c}\text { Paroxysmal } \\
\text { noctumal }\end{array}$ \\
\end{tabular} & 5 & 25.0 & 1 & 5.0 & 0 & 0 & 0 & 0 & 3.403 & 0.356 & 2 & 10.0 & 1 & 5.0 & 0 & 0 & 0 & 0 & 2.05 & 0.562 & 0.206 & 0.650 \\
\hline \#-Relieving factors of & & & & & & & & & & & & & & & & & & & & & & \\
\hline Rest & 0 & 0 & 5 & 25.0 & 5 & 25.0 & 7 & 35.0 & 30.28 & $0.0001^{*}$ & 0 & 0 & 9 & 45.0 & 2 & 10.0 & 0 & 0 & 6.150 & 0.104 & 13.635 & $0.0001^{*}$ \\
\hline $0^{2}$ therapy & 15 & 75.0 & 20 & 100 & 14 & 70.0 & 8 & 40.0 & 75.09 & $0.0001^{*}$ & 5 & 25.0 & 5 & 25.0 & 0 & 0 & 0 & 0 & 11.80 & $0.008 *$ & 40.025 & $0.0001 *$ \\
\hline Practice of IMT & 0 & 0 & 0 & 0 & 0 & 0 & 0 & 0 & 64.76 & $0.0001^{*}$ & 7 & 35.0 & 11 & 55.0 & 2 & 10.0 & 0 & 0 & 22.92 & $0.0001^{*}$ & 6.619 & $0.010^{*}$ \\
\hline Upright positioning & 15 & 75.0 & 20 & 100 & 19 & 95.0 & 15 & 75.0 & 9.573 & 0.144 & 7 & 35.0 & 11 & 55.0 & 2 & 10.0 & 0 & 0 & 17.50 & $0.001^{*}$ & 35.511 & $0.0001^{*}$ \\
\hline -Cyanosis: & & & & & & & & & & & & & & & & & & & & & & \\
\hline No cyanosis & 16 & 80.0 & 19 & 95.0 & 16 & 80.0 & 16 & 80.0 & 2.832 & 0.830 & 18 & 90.0 & 19 & 95.0 & 18 & 90.0 & 19 & 95.0 & 3.654 & 0.723 & 4.252 & 0.119 \\
\hline Central & 2 & 10.0 & 0 & 0 & 2 & 10.0 & 2 & 10.0 & & & 0 & 0 & 0 & 0 & 1 & 5.0 & 0 & 0 & & & & \\
\hline Penipheral & 2 & 10.0 & 1 & 5.0 & 2 & 10.0 & 2 & 10.0 & & & 2 & 10.0 & 1 & 5.0 & 1 & 5.0 & 1 & 5.0 & & & & \\
\hline
\end{tabular}

*Significant $(\mathbf{P}<0.05)$ 
Table 5: Occurrence of post-operative pulmonary complications (Melbourne Group Scale) (MGS) among the studied adult patients undergoing cardiothoracic surgeries.

\begin{tabular}{|c|c|c|c|c|c|c|}
\hline \multirow[t]{3}{*}{$\begin{array}{l}\text { Post-operative pulmonary } \\
\text { complications at post-operative days of } \\
\text { follow up }\end{array}$} & \multicolumn{4}{|c|}{$\begin{array}{l}\text { The studied adult patients } \\
\text { undergoing cardiothoracic } \\
\text { surgeries } \\
(\mathrm{n}=40)\end{array}$} & \multirow[t]{3}{*}{$\chi^{2}$} & \multirow[t]{3}{*}{$\mathbf{P}$} \\
\hline & \multicolumn{2}{|c|}{$\begin{array}{l}\text { Control group } \\
(n=20)\end{array}$} & \multicolumn{2}{|c|}{$\begin{array}{c}\text { Study group } \\
(\mathbf{n}=\mathbf{2 0})\end{array}$} & & \\
\hline & $\mathbf{n}$ & $\%$ & $\mathbf{N}$ & $\%$ & & \\
\hline $\begin{array}{l}\text {-1 } \\
\text { No post-operative day: } \\
\text { Significant pulmonary } \\
\text { complications }\end{array}$ & $\begin{array}{c}8 \\
12\end{array}$ & $\begin{array}{l}40.0 \\
60.0\end{array}$ & $\begin{array}{c}12 \\
8\end{array}$ & $\begin{array}{l}60.0 \\
40.0\end{array}$ & 1.600 & 0.206 \\
\hline $\begin{array}{l}\mathbf{3}^{\text {rd }} \text { post-operative day: } \\
\text { No complications } \\
\text { Significant pulmonary complications } \\
\end{array}$ & $\begin{array}{c}7 \\
13 \\
\end{array}$ & $\begin{array}{l}35.0 \\
65.0 \\
\end{array}$ & $\begin{array}{c}13 \\
7 \\
\end{array}$ & $\begin{array}{l}65.0 \\
35.0 \\
\end{array}$ & 3.600 & 0.058 \\
\hline $\begin{array}{l}\boldsymbol{- 5}^{\text {th }} \text { post-operative day: } \\
\text { No complications } \\
\text { Significant pulmonary complications } \\
\end{array}$ & $\begin{array}{c}6 \\
14 \\
\end{array}$ & $\begin{array}{l}30.0 \\
70.0 \\
\end{array}$ & $\begin{array}{c}14 \\
6 \\
\end{array}$ & $\begin{array}{l}70.0 \\
30.0 \\
\end{array}$ & 6.400 & $0.011^{*}$ \\
\hline $\begin{array}{l}\text { - } 7^{\text {th }} \text { post-operative day: } \\
\text { No complications } \\
\text { Significant pulmonary complications }\end{array}$ & $\begin{array}{c}8 \\
12 \\
\end{array}$ & $\begin{array}{l}40.0 \\
60.0 \\
\end{array}$ & $\begin{array}{c}15 \\
5\end{array}$ & $\begin{array}{l}75.0 \\
25.0 \\
\end{array}$ & 5.013 & $0.025^{*}$ \\
\hline
\end{tabular}

${ }^{*}$ Significant $(\mathrm{P}<0.05)$

Table 6: Mean values of post-operative duration of mechanical ventilation andO2 therapy among the studied patients

\begin{tabular}{|c|c|c|c|c|}
\hline \multirow[t]{2}{*}{$\begin{array}{l}\text { Post-operative duration of } \\
\text { mechanical ventilation and } \mathrm{O} 2 \\
\text { duration therapy }\end{array}$} & \multicolumn{2}{|c|}{$\begin{array}{l}\text { The studied adult patients undergoing } \\
\text { cardiothoracic surgeries } \\
(\mathrm{n}=40)\end{array}$} & \multirow[t]{2}{*}{ t-test } & \multirow[t]{2}{*}{$\mathbf{P}$} \\
\hline & $\begin{array}{l}\text { Control group } \\
(\mathrm{n}=\mathbf{2 0})\end{array}$ & $\begin{array}{l}\text { Study group } \\
(\mathrm{n}=\mathbf{2 0})\end{array}$ & & \\
\hline $\begin{array}{l}\text {-Duration of post-operative } \\
\text { mechanical ventilation (hours): } \\
\text { Range } \\
\text { Mean } \pm \text { SD }\end{array}$ & $\begin{array}{l}0-15 \\
5.25 \pm 4.49\end{array}$ & $\begin{array}{l}2-8 \\
2.60 \pm 2.37\end{array}$ & 2.332 & $0.025^{*}$ \\
\hline $\begin{array}{l}\text {-Duration of } \mathrm{O} 2 \text { therapy (hours): } \\
\text { Range } \\
\text { Mean } \pm \text { SD }\end{array}$ & $\begin{array}{l}1-9 \\
5.15 \pm 2.16\end{array}$ & $\begin{array}{l}0.62-7 \\
2.36 \pm 1.99 \\
\end{array}$ & 4.251 & $0.0001 *$ \\
\hline
\end{tabular}

*Significant $(\mathbf{P}<\mathbf{0 . 0 5})$

Figure 2: Need for post-operative re-intubation and chest tube re-insertion among the studied adult patients

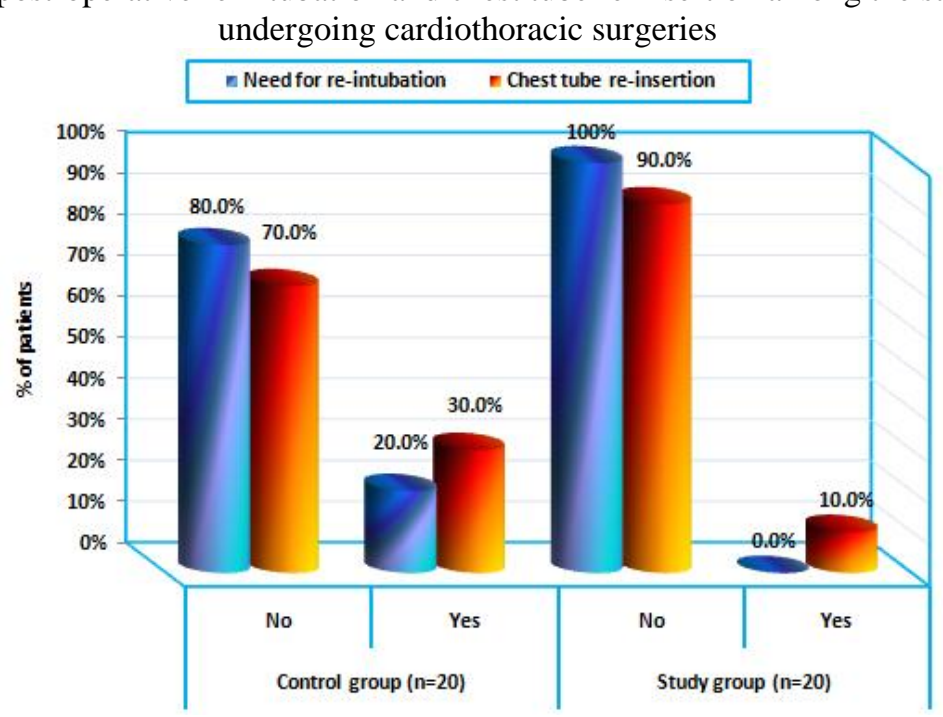


Table 7: Mean values of duration of post-operative ICU admission and total period of hospitalizationamong the studied adult patients

\begin{tabular}{|c|c|c|c|c|}
\hline \multirow[t]{2}{*}{$\begin{array}{l}\text { Post-operative ICU } \\
\text { admission and Total period } \\
\text { of hospitalization. }\end{array}$} & \multicolumn{2}{|c|}{$\begin{array}{l}\text { The studied adult patients } \\
\text { undergoing cardiothoracic } \\
\text { surgeries } \\
(\mathrm{n}=40)\end{array}$} & \multirow[t]{2}{*}{ t-test } & \multirow[t]{2}{*}{$\mathbf{P}$} \\
\hline & $\begin{array}{c}\text { Control group } \\
(n=20)\end{array}$ & $\begin{array}{c}\text { Study group } \\
(\mathbf{n}=\mathbf{2 0 )}\end{array}$ & & \\
\hline $\begin{array}{l}\text { - Duration of post-operative } \\
\text { ICU admission (days): } \\
\text { Range } \\
\text { Mean } \pm \text { SD }\end{array}$ & $\begin{array}{c}4-17 \\
8.70 \pm 3.96\end{array}$ & $\begin{array}{c}2-9 \\
4.55 \pm 2.26\end{array}$ & 4.070 & $0.0001^{*}$ \\
\hline $\begin{array}{l}\text { - Total period of } \\
\text { hospitalization (days): } \\
\text { Range } \\
\text { Mean } \pm \text { SD }\end{array}$ & $\begin{array}{c}9-35 \\
20.40 \pm 8.83\end{array}$ & $\begin{array}{c}9-30 \\
15.20 \pm 8.11\end{array}$ & 1.939 & 0.060 \\
\hline
\end{tabular}

*Significant $(\mathrm{P}<0.05)$

Figure 3: Need for postoperative ICU readmission among the studied adult patients undergoing cardiothoracic surgeries

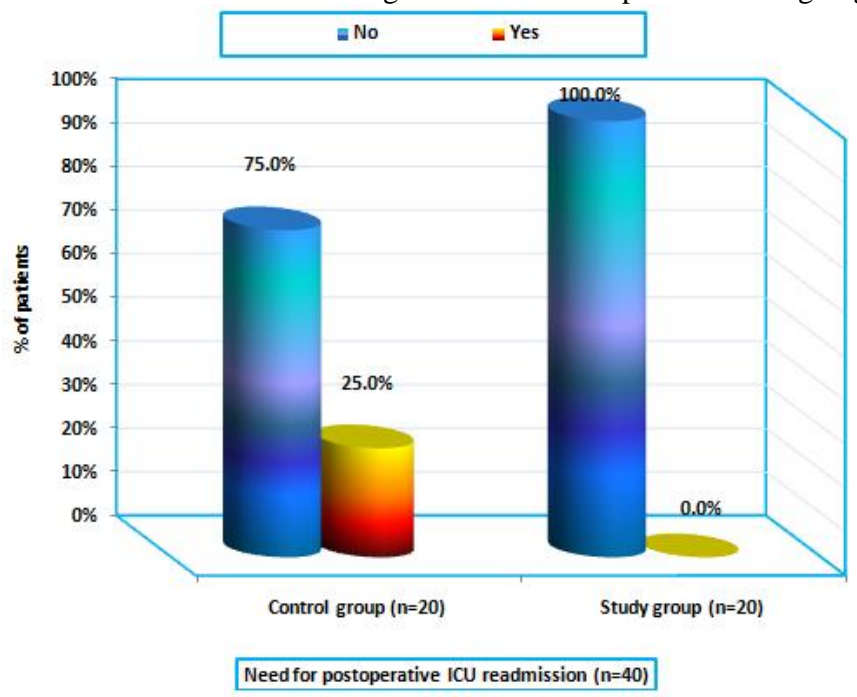

\section{Discussion}

Characteristics of the study Sample; the findings of the present study revealed that the mean age of the studied groups was 40.70 years. This finding was in line with Alaparthi et.al, (2013) $\left({ }^{42)}\right.$ who found that the mean age of the studied sample was 40.4 years. On the other hand, this result was disagreed by Spruit et.al, $2006^{(43)}$, Jones et.al, $2007^{(44)}$ and Granger et. al, $2013^{(45)}$ who concluded that the mean age of their studied groups was 65 years. Leroy et.al, (2010) ${ }^{(46)}$ found that the mean age of the studied groups was 32 years. Similarly,this result was contradicted byArbane et.al, (2010) ${ }^{(47)}$ and Hoffman et.al, (2013) ${ }^{(48)}$ whostated that the mean age of their studied sample was 64 years. Also, Coats et.al, (2013) ${ }^{(49)}$ mentioned that the mean age of the studied sample was 59 years. Bissett et.al, (2014) ${ }^{(50)}$ found that themean age of the studied sample was 61.6 years.

In relation to sex, the current study showed that nearly half of the studied groups were females. This finding was similar to the findings of Hulzebos et.al, $(2006)^{(51)}$, Benzo et.al, (2011) ${ }^{(52)}$ and Granger et.al, $(2013)^{(45)}$ who reported that nearlyhalf of the studied sample were males. SimilarlyCoats et.al, (2013) ${ }^{(49)}$ andCondessa et.al, (2013) ${ }^{(53)}$ concluded that half of the studied patients were females and the other half was males. On the other hand, this result was contradicted by Jones et.al, $(2007)^{(44)}$ who found that the majority of the studied sample was females. Cader et.al, (2010) ${ }^{(54)}$ observed that more than half of the studied groups in their study were females. Martin et.al,(2011) ${ }^{(55)}$, Kodric et.al, (2013) ${ }^{(56)}$ andShakouri et.al, $(2015)^{(57)}$, who concluded that majorityof the studied groups were males. 
As regard to marital status, the findings of the current study revealed that half of the studied groups were married. This finding was in accordance with Ellis et.al, (2012) ${ }^{(58)}$ whofound that more than half of the studiedgroups were married.

In relation to educational level, the finding of the current study revealed that less than half of the studied sample had secondary education. The finding of the present study was disagreed by Ellis et.al, (2012) ${ }^{(58)}$ andMolassiotis et.al, (2015) ${ }^{(59)}$ whoobserved that majority of the studied groups had secondary education. Concerning occupation, the findings of the present study revealed that less than half of the studied sample was manual workers. This may be due to low educational level of the studied patients in the current study. This finding was contradicted by Ellis et.al, (2012) ${ }^{(58)}$ andMolassiotis et.al, $(2015)^{(59)}$ who reported that majority of the studied sample were retired.

Regarding the type of cardiothoracic surgery, the findings of the present study revealed that the majority of studied groups had coronary artery bypass graft (CABG) surgery, valve surgery and pneumectomy. This finding was in agreement with by Crisafulli et.al, $(2013)^{(60)}$ and Valkenet et.al, $(2013)^{(61)}$ who found that the majority of studied groups had coronary artery bypass graft surgery and valve surgery. Also, Kodric et.al, (2013) (56) reported that the majority of the studied groups underwent coronary artery bypass graft surgery. Concering arterial blood gases (ABGs) results, the present study showed a statistical significant difference of PH in the study group was towards the normal range during the $3^{\text {rd }}$ post-operative day. The findings of the current study also revealed that $\mathrm{pao}_{2}$ and sao2 were higher in the study group than in the control group. No statistical significant difference was found between control and study group in relation to Paco2. These improvements in arterial blood gases may be explained by improvement in the patient's breathing patterns (as slow deep breathing that resulted from redemonstration of inspiratory muscle training in study group versus shallow rapid breathing in control group). Also, diaphragmatic breathing pulls oxygen into the deepest lobes of the lungs where a better gas exchange occur thus enhancing delivery of oxygen and nutrients to the tissues and removing carbon dioxide. These findings were agreed by $\boldsymbol{E l}$ Badawy et.al, (2007) ${ }^{(62)}$ who found statistical significant improvements in arterial blood gases $\left(\mathrm{PH}\right.$ and $\left.\mathrm{PaO}_{2}\right)$ after using inspiratory muscle training andAly et.al,(2007) ${ }^{(63)}$ who stated that there were significant improvements of the arterial blood gases after the application of inspiratory muscle training. Additionally, the findings of the current study were incongruent with Restrepo et.al, (2011) ${ }^{(64)}$ who concluded that pre and post-operative use of incentive spirometry improved arterial oxygenation $\left(\mathrm{PaO}_{2}, \mathrm{SaO}_{2}\right)$. Chawla et.al, (2013) ${ }^{(65)}$ showed that the level of arterial oxygen saturation significantly increased after inspiratory muscle training. Also, Brocki et.al, (2015) ${ }^{(66)}$ reported that $\mathrm{Spo}_{2}$ was improved in the study group on the third and fourth postoperative days.

In contrast, the result of the current study was in disagreement with by Ferreira et.al, $2009{ }^{(67)}$ who found that arterial $\mathrm{PaO}_{2}$ was increased in the control and the study group immediately after extubation, but this increase was not statistically significant due to routine oxygen supplementation to all patients within the first 12 hours after surgery. Additionally, Bavarsad et.al, (2015) ${ }^{(68)}$ observed a slight but non-significant increase in oxygen saturation in the inspiratory muscle training group, where as it remained unchanged in the control group.

I In relation to the rate of respiration, the result of the current study presented that respiratory rate was lowered toward the normal limit in the study group than in the control group. Deep, regular and symmetrical breathing was higher in the study group than in the control group. With regard to respiratory sounds, the present study revealed that clear right and left lung sounds were higher in the study group than in control group during post-operative days. In addition diminished breath sound and crackles were lower in study group than control group. The findings of the present study were agreed byRestrepo et.al, $(2011)^{(64)}$ who reported that pre and post-operative use of incentive spirometry decreased respiratory rate and improved previously absent or diminished breath sounds. Elbouhy et.al, (2011) ${ }^{(69)}$ found decrease in respiratory rate toward the normal limit in the inspiratory muscle training group than in the control group and this reduction was statistically significant which may be due to more accommodation of the patient to training. Moreover, the finding of the present study was supported by Elkins et.al, (2105) ${ }^{(70)}$ who found that inspiratory muscle training significantly improved rapid shallow breathing in the study than in the control group. On the other hand, the findings of the present study were contradicted by Condessa et.al, (2013) ${ }^{(53)}$ who proved that shallow rapid breathing was decreased in the control and inspiratory muscle training group during weaning off mechanical ventilation.

In relation to dyspnea,the findings of the current study presented that dyspnea at rest and on exertion were higher in the control group than in study group. $\mathrm{O}_{2}$ therapy was the essential relieving factor of the patients, while inspiratory muscle training was the essential relieving factor of dyspnea in the study group. This result may be due to improved lung expansion and pulmonary volumes associated with inspiratory muscle training. 
The findings of the present study came in accordance withthe findings of Mancini et.al, 2010 ${ }^{(71)}$ who stated that the study group who received inspiratory muscle training reported a subjective improvement in dyspnea during the activities of daily livingBosnak-Guclu et.al, (2011) ${ }^{(72)}$ and Huang et.al, (2011) ${ }^{(73)}$ who reported that inspiratory muscle training significantly alleviated dyspnea in the study group compared with control group. Also, Mohamed (2012) ${ }^{(74)}$ found that inspiratory muscle training significantly increased inspiratory muscle strength and endurance and resulted in decrease in dyspnea sensation at rest and during exercises. Moreover, the findings of the current study were supported by Kodric et.al, (2013) ${ }^{(56)}$ whoconcluded that training of inspiratory muscles has a positive effect on dyspnea and activities of daily living. Crisafulli et.al, (2013) ${ }^{(60)}$ observed that dyspnea improved faster and more significantly in the study when compared with control group. In contrast, Jeong et.al, (2015) ${ }^{(75)}$ found that dyspnea was reduced in the study group but this reduction was not statistically significant.

As regard mean duration of post-operative mechanical ventilation, the findings of the current study concluded that mean duration of mechanical ventilation was significantly more in the control group than in study group. The finding of the present study was in line with Elkins et.al,(2015) ${ }^{(70)}$ who revealed that total duration of mechanical ventilation was shorter in the inspiratory muscle training group. On the other hand, the finding of the current study was in contrast with Condessa et.al, (2013) ${ }^{(53)}$ whostated that inspiratory muscle training didn't accelerate weaning from mechanical ventilation. Lunardi et.al, (2011) (13) reported that inspiratory muscle training in routine care wasn't resulted in decreased ventilation time.

Regarding the need for re-intubation, the finding of the current study revealed that none of the study group needed re-intubation compared to small percent of the control group and this may be attributed to the reduction in the incidence of post-operative pulmonary complications in the study group, beside that none of the study group developed neither acute respiratory distress syndrome nor acute respiratory failure in the postoperative days. The finding of the current study was in handwithLunardi et.al, (2010) ${ }^{(76)}$ who stated that re-intubation for respiratory failure was lower in the study group than in control group. In contrast, the findings of the current study were contradicted by Elkins et.al, (2105) ${ }^{(70)}$ who found that no statistical significant difference found between the two groups in relation to the need for re-intubation.

As regard chest tube re-insertion, the findings of the current study revealed that the need for chest tube reinsertion was lower in the study group than in control group and this may be attributed to the protective effect of inspiratory muscle training in the study group which resulted in reduction in the incidence of post-operative pulmonary complications such as pneumothorax and pleural effusion which needed chest tube re-insertion. This finding was agreed byLunardi et.al, (2010) ${ }^{(76)}$ who concluded that postoperative inspiratory muscle training reduced the rate of respiratory complications, thoracic drainage time, the need to return to mechanical ventilation and the need for chest tube re-insertion.

In relation to the duration of intensive care unit stay, the findings of the current study revealed a significant reduction of post-operative stay in intensive care unit in the study than in control group. This result may be due to reduction of the incidence or the severity of post-operative pulmonary complications in the patients of the study group. The finding of the present study was in accordance withMatheus et.al, (2012) ${ }^{(77)}$ who showed a significant reduction in length of stay in the coronary care unit in the study group. Also, Elkins et.al, (2105) ${ }^{(70)}$ found that inspiratory muscle training significantly shortened the length of stay in the ICU.

As regard total days of hospitalization, the finding of the current study revealed that there was no statistical significant difference between the two groups regarding the duration of hospitalization. This result may be due to complications other than post-operative pulmonary complications such as post-operative cardiac, neurological or renal complications. The finding of the present study was in line with Lunardi et.al, (2011) ${ }^{(13)}$ who stated that inspiratory muscle training in routine care wasn't resulted in decreased length of hospital stay.

On the other hand, the finding of the present study was in disagreement with Arbane et.al, (2011) ${ }^{(47)}$ who stated that period of hospitalization was longer in the control than in the study group. Additionally, Mohamed (2012) (74) concluded that inspiratory muscle training significantly shortened the duration of postoperative hospitalization in patients underwent thoracic surgery.

\section{Conclusion and Recommendations}

Based on the findings of the present study, it can be concluded that: Inspiratory muscle training is an effective nursing strategy in improving patient's outcomes after cardiothoracic surgery. Inspiratory muscle training is easy, cost effective and non-invasive procedure which helped in reducing the incidence of postoperative pulmonary complications, prevents re-intubation, chest tube re-insertion, decrease duration of ICU 
stay and prevents the need for IUC re-admission. Inspiratory muscle training is effective when it was taught to the patient in the pre-operative period. Inspiratory muscle training had a positive effect on dyspnea at rest and during exertion and even if the patient experienced dyspnea, practice of inspiratory muscle training exercises helped in relieving it.

\section{In the light of the current study findings, the following recommendations are suggested:}

For patients: those who scheduled for cardiothoracic surgery should be provided with both written and verbal information about techniques of inspiratory muscle training. Inspiratory Muscle Training should be taught to patients preoperatively in several sessions until the patient performs the technique efficiently, correctly and independently. Patients should redemonstrate postoperative inspiratory muscle training immediately after extubation.

For nurses: In-service training programs should be conducted periodically for the nurses in the critical care unit to improve and update their knowledge about inspiratory muscle training. Inspiratory muscle training techniques should be used as a routine nursing intervention for all post-operative patients.

\section{References}

[1] Finkelmeier B. Cardiothoracic Surgical Nursing. $5^{\text {th }}$ ed. New York. Lippincott Williams and Wilkins com. 2009 ; 9: 99-111.

[2] Lesser D. Cardiac Surgery Manual for Nurses Orientation, Policy and Procedures. $3^{\text {rd }}$ ed. USA. $2007 ; 6$ : $29-41$.

[3] http://en.wikipedia.org/wiki/Cardiothoracic surgery, Retrieved on 20/4/2015.

[4] Al-Qubati F. Incidence and outcome of pulmonary complications after open cardiac surgery. Egyptian Journal of Chest Diseases and Tuberculosis. 2013;62(4): 775- 80.

[5] Statical analysis of Tanta University Hospital, 2014.

[6] Arafat A. Chest Complications of Open Heart Surgery. Master thesis in General Surgery. Faculty of Medicine. Tanta University. 2006: 52-60.

[7] Qiang J, Yunqing M, Wang X andFeng J. Risk factors for pulmonarycomplications following cardiac surgery with cardiopulmonary bypass. International Journal of Medical Science. 2013; 10(11): 4-19.

[8] Canet J and Mazo V. Postoperative Pulmonary Complications. MineveraAnesthesiologica. 2010; $76(2): 138$ - 42.

[9] Agostini P, Cieslik H, Rathinam S and Bishay E. Postoperative pulmonary complications following thoracic surgery: are there any modifiable risk factors? Thorax Journal. 2010; 65(9): 815-18.

[10] Urell Charlotte. Lung Function, Respiratory Muscle Strength and Effects of Breathing Exercises in Cardiac Surgery Patients. Faculty of Medicine. Uppsala University. 2013; 9-15.

[11] Morsch K, Leguisamo C, Camargo $\mathrm{M}$ and Coronel C. Ventilatory profile of patients undergoing CABG surgery. Critical Cardiovascular Journal. 2009; 24(2): 180- 87.

[12] Evans J and Whitelaw W. The assessment of maximal respiratory mouth pressures in adults. Journal of Respiratory Care. 2009; 54(10): 1348- 59.

[13] Ferreira P, Rodrigues A, Mendes V, Xavier M and Augusto V. Preoperative respiratory muscle dysfunction is a predictor of prolonged invasive mechanical ventilation in cardiorespiratory complications after heart valve surgery. European Journal of Cardiothoracic Surgery. 2011; 39(5): 662- 66.

[14] Sellke F, Nido P and Swanson S. Sabiston\&Spencer Surgery of the Chest. $8^{\text {th }}$ ed. USA. Elsevier com. 2010; 6: 39-60.

[15] Richard M and Peters W. International Practice in Cardiothoracic Surgery. USA. Springer com. 2008; 10: 90- 95.

[16] Karen K. AACN Advanced Critical Care Nursing. $4^{\text {th }}$ ed. Canada. Elsevier com. 2009; 12: 314-17.

[17] Piwoda A and Jastrzebeska B. Optimization of early rehabilitation of patient undergoing Cardio-Surgical Intervention. Cardiovascular surgery and transplantology department. Jagiiellonian university medical college.2005; 9(2): $26-33$.

[18] Ferreira G, Haeffner M, Barreto S and Dall'Ago P. Incentive spirometry with expiratory positive airway pressure brings benefits after myocardial revascularization. Arq Bras Cardiol. 2010; 94(2): 230- 35.

[19] Peate I, Wild K and Nair M. Nursing Practice: Knowledge and Care. $3^{\text {rd }}$ ed. USA. Wiley Blackwell com. $2014 ; 14: 272-88$.

[20] Ehrman J, Gordon P, Visich P and Keteyian S. Theraputic Exercises for Physical Therapist Assistants. $3^{\text {rd }}$ ed. USA. Human Kinetic Amazon com. 2013; 17: 327- 29.

[21] Chickwe J, Cooke D and Weiss A. Cardiothoracic Surgery. $2^{\text {nd }}$ ed. China. Amazon com. 2013; 4,5,13: 102- 56, 643- 61.

[22] McConnell A. Respiratory Muscle Training: Theory and Practice. $1^{\text {st }}$ ed. London. Elsevier Com. $2013 ; 4$ : $1180-86$.

[23] Hodson M, Bush A and Geddes D. Cystic Fibrosis. $3^{\text {rd }}$ ed. UK. CRC Press com. 2007; 25: $365-77$.

[24] Siafakas N. European Respiratory Monograph 38: Management of Chronic Obstructive Pulmonary Disease. 11 thed. UK. European Respiratory Society com. 2006; 24: 342- 45.

[25] Celso R, Denise M and Adriana C. Incentive spirometry in major surgeries. Physical Therapy Journal. 2011; 15(5): $343-46$.

[26] Allbee B, Marcucci L and Monty J. Avoiding Common Nursing Errors. $5^{\text {th }}$ ed.USA. Lippincott Williams and Wilkins com. 2010; 10: $346-47$.

[27] Restrepo RD, Tracy M, Wettstein R and Wittnebel L. Incentive Spirometry. Journal of Respiratory Care. $2011 ; 56(10): 1600-604$.

[28] Kodric M, Trevisan R, TorregianiCh, Cifaldi R and Longo C. Inspiratory muscle training for diaphragm dysfunction after cardiac surgery. The Journal of Thoracic and Cardiovascular Surgery. 2012; 12(7): 1-4.

[29] Hoeman Sh. Rehabilitation Nursing: Prevention, Intervention, and Outcomes. $4^{\text {th }}$ ed. Elsevier com. USA. $2008 ; 7: 14-40$.

[30] Lawrence V. Strategies to reduce postoperative pulmonary complications after noncardiothoracic surgery. Ann Internal; Medicine. 2006; 144 (5): 111- 23.

[31] Sarkar A, Sharma H, RazdanSh and Kuhar S. Effect of Segmental Breathing Exercises on Chest Expansion in Empyema Patients. Indian Journal of physiotherapy \& Occupational Therapy. 2010; 4(3): 17- 20.

[32] Keogh J. Nursing Laboratory and Diagnostic Tests. 1 sted. USA. McGraw Hill com. 2011; 1 - 150.

[33] El- Kader Sh. Blood Gases Response to Different Breathing Modalities in Phase I of Cardiac Rehabilitation Program after Coronary Artery Bypass Graft. European Journal of General Medicine. 2011; 8(2): 85- 91. 
[34] Parsonnet V, Dean D and Bernstein A. A method of uniform stratification of risk for evaluating the results of surgery in acquired adult heart Disease .1989; 79(6): 1-11.

[35] Boone T. Introduction to Exercise Physiology. $1^{\text {st }}$ ed. USA. Amazon com. 2014; 7 : 107- 50.

[36] Holmes N. Lippincott Manual of Nursing Practice Series Assessment. $4^{\text {th }}$ ed. London. Lippincott Williams \& Wilkins com. 2007; 3: 42-77.

[37] Bradley A, Marshall A, Abdelaziz M, HussainKh and Agostini P. Thoracoscorefail to predict complications following elective lung resection. European Respiratory Journal. 2012; 40 (6): 1496- 501.

[38] Ferreira P, Rodrigues A and Evora P. Effects of an inspiratory muscle rehabilitation program in the postoperative period of cardiac surgery. Arq Bras Cardiol. 2009; 92(4): 275- 82.

[39] Arthur HM, Daniels C, McKelvie R and Hirsh J. Effect of a preoperative intervention on preoperative and postoperative outcomes in low-risk patients awaiting elective coronary artery bypass graft surgery. A randomized, controlled trial. Annual Internal Medicine. 2000; 133: 253- 62.

[40] Acton A. Post-Operative Complications: New Insights for the Healthcare Professional. $1^{\text {st }}$ ed. USA. Amazon com. 2013 ; 1 : $3-6$.

[41] Dawson B D and Trapp R G: Reading the medical literature: Basic \& Clinical Biostatistics. Lange Medical Book/ McGraw - Hill. $3^{\text {rd }}$ ed. New York. Medical Publication Division com. 2010; 9: 161- 314.

[42] Alaparthi P, Calvert R, Subramanian H and Naidu B. Is incentive spirometry effective following thoracic surgery? Interactive Cardiovascular and Thoracic Surgery. 2013; 7(2): 297- 300.

[43] Spruit MA, Janssen PP, Willemsen S and Hochstenbag M. Exercise capacity before and after an 8-week multidisciplinary inpatient rehabilitation program in lung cancer patients: a pilot study. Lung Cancer. 2006; 52(2): 257- 60.

[44] Jones LW, Eves ND, Spasojevic I and Wang F. Effects of aerobic training on oxidative status in postsurgical non-small cell lung cancer patients: a pilot study. Journal of Lung Cancer. 2007; 72(1): 45- 51.

[45] Granger CL, Chao C, McDonald CF, Berney S and Denehy L. Safety and feasibility of an exercise intervention for patients following lung resection: a pilot randomized controlled trial. Journal of Integral Cancer Therapy. 2013; 12(3): 213 - 24.

[46] Leroy S, PerezTh, Neviere R, Aguilaniu B and Wallaert B. Determinants of dyspnea and alveolar hypoventilation during exercise in cystic fibrosis: Impact of inspiratory muscle endurance. Journal of Cystic Fibrosis. 2010; 10 (2011): $159-65$.

[47] Arbane G, Tropman D, Jackson D and Garrod R. Evaluation of an early exercise intervention after thoracotomy for non-small cell lung cancer (NSCLC), effects on quality of life, muscle strength andexercise tolerance: randomized controlled trial. Lung Cancer 2010; 71(2): 229-234.

[48] Hoffman AJ, Brintnall RA, Brown JK, Eye A and Jones LW. Too sick not to exercise: using a 6-week, home-based exercise intervention for cancer related fatigue self-management for postsurgical non-small cell lung cancer patients. Journal of Cancer Nurses. 2013; 36(3): 175-88.

[49] Coats V, Maltais F, Simard S, Frechette E and Tremblay L. Feasibility and effectiveness of a home-based exercise training program before lung resection surgery. Journal of Cancer Thoracic Society. 2013; 20(2): 10-16.

[50] Bissett B, Leditschke A, Boots R and Paratz J. Weaned but weary: One third of adult intensive care patients mechanically ventilated for 7 days or more have impaired inspiratory muscle endurance after successful weaning. Journal of Heart\& Lung. 2014; 44 (2015): 15-20.

[51] Hulzebos E, Helders P, Faviie' NJ and Riviere A. Preoperative Intensive Inspiratory Muscle Training to Prevent Postoperative Pulmonary Complications in High-Risk Patients Undergoing CABG Surgery. JAMA. 2006; 296: 1851 - 57.

[52] Benzo R, Wigle D, Novotny P and Wetzstein M. Preoperative pulmonary rehabilitation before lung cancer resection: results from two randomized studies. Lung Cancer. 2011; 74(3): 441- 45.

[53] Condessa R, Brauner J, Saul A and Baptista M. Inspiratory muscle training did not accelerate weaning from mechanical ventilation but did improve tidal volume and maximal respiratory pressures: a randomized trial. Journal of Physiotherapy. 2013; 59: 101- 6.

[54] Cader SA, Vale RG, Castro JC and Bacelar SC. Inspiratory muscle training improves maximal inspiratory pressure and may assist weaning in older intubated patients. Journal of Physiotherapy. 2010; 56 (7): 171- 77.

[55] Martin D, Smith K, Davenport P and Harman E. Inspiratory muscle strength training improves weaning outcome in failure to wean patients. Journal of Physiotherapy. 2011; 15 (84): 2- 12.

[56] Kodric M, Trevisan R, TorregianiCh and Cifaldi R. Inspiratory muscle training for diaphragm dysfunction after cardiac surgery. The Journal of Thoracic and Cardiovascular Surgery. 2012; 12(7): 1-4.

[57] Shakouri S, Salekzamani Y, Taghizadieh A, Jaded H and SahebiR.Effect of Respiratory Rehabilitation Before Open Cardiac Surgery on Respiratory Function. Journal of Cardiovascular Thoracic. 2015; 7(1): 13-17.

[58] Ellis J, Tishelman C, Bailey Ch and Lorigan P. Considerations in Developing and Delivering a Non-pharmacological Intervention for Symptom Management in Lung Cancer: The Views of Patients and Informal Caregivers. Journal of Pain and Symptom Management.2012; 44(6):831- 40.

[59] Molassiotis A, Charalambous Aand Taylor P. The effect of resistance inspiratory muscle training in the management of breathlessness in patients with thoracic malignancies. Journal of Support Care Cancer. 2015; 23: 1637- 45.

[60] Crisafulli E, Venturelli E, Siscaro G, Florini F and Papetti A. Respiratory Muscle Training in Patients Recovering Recent Open Cardiothoracic Surgery: A Randomized-Controlled Trial. BioMed Research International. 2013; 7 (2): 2-6.

[61] Valkenet K, Heer F, Hulzebos E and Kwant S. Effect of Inspiratory Muscle Training Before Cardiac Surgery in Routine Care. Journal of American physical therapy association. 2013; 95 (7): 1-9.

[62] El Badawy M, Abd El Raheem S, Sharf EL-din M and Sayed A. Effect of Inspiratory Muscle Training on Selected Blood Gases in Chronic Obstructive Pulmonary Disease Patients. Master Thesis of Msc. Faculty of Medicine. Cairo University. 2007: 1-4.

[63] Aly F, El-Sayed A and Shanub Al. Effect of Inspiratory Muscle Training on Blood Gases in Patients with Chronic Obstructive Lung Disease. Physical Therapy Department for Cardiopulmonary Disorders and Geriatric, Faculty of Physical Therapy, Cairo University. 2007; 12 (2): 228-32.

[64] Restrepo R, Wettstein R, Wittnebel L, and Tracy M. AARC Clinical Practice Guideline Incentive Spirometry. Respiratory Care. 2011; 56 (10): 1602- 603.

[65] Chawla S, Narwal R and Rawat J. Comparison of Inspiratory Muscle Training and Rib Raising Technique in Pulmonary Diseases Subjects. Indian Journal of Physiotherapy and Occupational Therapy. 2013;7(2):150- 55.

[66] Brocki BC, Andreasen JJ, Langer D, Souza DS and Westerdahl E. Postoperative inspiratory muscle training in addition to breathing exercises and early mobilization improves oxygenation in high-risk patients after lung cancer surgery. European Journal of Cardiothoracic Surgery. 2015;20(10): 359-61.

[67] Ferreira P, Rodrigues A and Évora B. Effects of an inspiratory muscle rehabilitation program in the postoperative period of cardiac surgery. Arq. Bras. Cardiol. 2009; 92 (4): 17-25. 
[68] Bavarsad M, Shariati A, Idani E, Zaheri H and Latifi S. Inspiratory Muscle Training and Arterial Blood Oxygen Saturation in Patients With Chronic Obstructive Pulmonary Disease. Journal of Chronic Disease Care. 2015; 4(1): 2-4.

[69] ElbouhyC, Paisani D, Lunardi A. Incentive spirometry in major surgeries: a systematic review. RevistaBrasileira de Fisioterapia. 2011; 15(5): 343-50

[70] Elkins M and Dentice R. Inspiratory muscle training facilitates weaning from mechanical ventilation among patients in the intensive care unit. Journal of Physiotherapy.2015; 61 (1) 127- 34.

[71] Mancini D, Henson D, Manca J, Donchez L and Levine S. Benefit of Selective Respiratory Muscle Training on Exercise Capacity in Patients With Chronic Congestive Heart Failure. 2010; 91(14): s320- 29.

[72] Bosnak-Guclu M, Arikan H, Savci S and Tulumen E. Effects of inspiratory muscle training in patients with heart failure. Journal of Respiratory Medicine. 2011; 105(20): 1671- 81.

[73] Huang Ch, Yang G, and Lee Ch. Comparison of Inspiratory Muscle Strength Training Effects Between Older Subjects With and Without Chronic Obstructive Pulmonary Disease. Journal of the Formosan Medical Association. $2011 ; 110$ (8): $518-26$.

[74] Mohamed F. Does Inspiratory Muscle Training Following Thoracic Surgery Have an Effect On The Outcomes? Journal of American Science. 2012; 8(3): 140- 43.

[75] JeongU, Enright S and Busse M. Management of respiratory problems in people with neurodegenerative conditions: a narrative review. Journal of Physiotherapy. 2015; 98 (12): 1-12.

[76] LunardiA,Cecconello I and Carvalho C. Postoperative chest physical therapy prevents respiratory complications in patients undergoing esophagectomy. Rev Bras Fisioter. 2010; 15(2): 160-5.

[77] Matheus G, Dragosavac D, Trevisan P, Costa C and Lopes M. Inspiratory muscle training improves tidal volume and vital capacity after CABG surgery. Rev Bras Cir Cardiovasc. 2012; 27 (3): 1-6. 